\title{
Differential response of grazing and bacterial heterotrophic production to experimental warming in Antarctic waters
}

\author{
Dolors Vaqué $^{1, *}$, Òscar Guadayol ${ }^{1,2}$, Francesc Peters ${ }^{1}$, Jordi Felipe ${ }^{1}$, \\ Andrea Malits ${ }^{1,3}$, Carlos Pedrós-Alió ${ }^{1}$ \\ ${ }^{1}$ Institut de Ciències del Mar, CSIC, Departament de Biologia Marina i Oceanografia, Passeig Maritim de la Barceloneta, \\ 37-49, 08003 Barcelona, Catalonia, Spain \\ ${ }^{2}$ College of Oceanic and Atmospheric Sciences, Oregon State University, 104 COAS Administration Building, Corvallis, \\ Oregon 97331-5503, USA \\ ${ }^{3} 47$, Chemin des Collettes, 06800 Cagnes sur Mer, France
}

\begin{abstract}
Narrow annual ranges of temperature characterize polar waters. Consequently, small increases in temperature could significantly affect the metabolic processes of marine microorganisms. We investigated the response of bacterial heterotrophic production (BHP) and grazing rates to small temperature changes in 3 zones near the western Antarctic Peninsula - Bransfield and Gerlache Straits, and Bellingshausen Sea-during December 2002. We performed 8 grazing experiments with water samples collected from depths where chlorophyll a (chl a) concentration was maximum, and incubated the samples at ambient temperature and at $-1,1,2$ and $5^{\circ} \mathrm{C}$. We expected that grazing would increase in parallel with BHP at increasing temperatures; however, temperature differentially affected these 2 microbial activities. Thus, grazing rates increased maximally at temperatures $\leq 2^{\circ} \mathrm{C}$, except in 1 station in the Gerlache Strait, while BHP increased maximally at temperatures $\geq 2^{\circ} \mathrm{C}$, except in 1 station in the Bellingshausen Sea. The percentage of grazed bacteria to BHP at the highest experimental temperatures was low $(56 \pm 19 \%)$ in the Gerlache Strait, high $(395 \pm 137 \%)$ in the Bransfield Strait and approximately balanced $(97 \pm 24 \%)$ in the Bellingshausen Sea. This suggests that differential microbial processes in each zone at increasing temperatures will also depend on the autochthonous community. The present study contributes to the understanding of the variability of polar biogeochemical fluxes, and may aid in predicting the response of microorganisms in future scenarios with local and seasonal changes in temperature.
\end{abstract}

KEY WORDS: Bacterial heterotrophic production $\cdot$ Grazing rates $\cdot$ Temperature $\cdot$ Antarctic waters Resale or republication not permitted without written consent of the publisher

\section{INTRODUCTION}

Antarctic surface-water temperature usually varies between -1.8 and $4^{\circ} \mathrm{C}$ (Longhurst 1998). There is strong evidence for a recent warming trend in the Southern Ocean (Bindoff et al. 2007) of up to $1^{\circ} \mathrm{C}$ (Meredith \& King 2005). While temperature changes affect all metabolic processes, they may do so at different rates for different processes, greatly altering ecosystem structure and functioning in waters with such narrow annual temperature ranges. The South- ern Ocean is considered to be one of the largest sinks of anthropogenic $\mathrm{CO}_{2}$ on Earth, and large increases in phytoplanktonic biomass and production have been recently predicted as a consequence of temperaturemediated major changes in stratification and length of the growth season (Sarmiento et al. 2004). As a result, one could expect increases in dissolved organic matter, bacterial production and biomass, grazing activity and respiration. The balances of carbon fluxes between these different processes, however, remain unknown. 
Low temperature is a potentially limiting factor for microorganisms. In permanently cold systems, most heterotrophic bacteria appear to be living at temperatures well below their optima for growth (Pomeroy \& Wiebe 2001). Many bacteria in cold waters are psychrophiles and psychrotolerants. The former are microorganisms that grow well at $-1.5^{\circ} \mathrm{C}$, have an optimal growth temperature at or below $15^{\circ} \mathrm{C}$ and do not grow above $20^{\circ} \mathrm{C}$ (Morita 1975). Psychrotolerant organisms are typically considered to be able to grow near freezing, but with optimum growth at $>20^{\circ} \mathrm{C}$ (Russell et al. 1990). Although both types of bacterial communities can grow in very cold waters, experiments using pure cultures have shown that psychrophilic bacteria do better than psychrotolerant bacteria at very low temperatures at the same substrate concentrations (Harder \& Veldkamp 1971). Pomeroy et al. (1991) examined the effect of a matrix of temperatures and substrate concentrations on respiratory rates of natural microbial assemblages taken from Newfoundland waters and found significant temperaturesubstrate interactions. Morán et al. (2006) studied how small increases in temperature induced changes in primary production during the same cruise as that of the present study. They carried out short-term temperature-increase experiments in the Southern Ocean showing that, while particulate primary production decreased or remained stable, the dissolved fraction increased. This was not always followed by an expected increase in bacterial production, showing a differential response of the 2 processes to temperature. Similar results were observed by Hoppe et al. (2008) in a mesocosm experiment in the Baltic Sea, while studying how small increases of temperature in winter affected the coupling between phytoplankton and bacteria during the spring bloom. Choi \& Peters (1992) described the effect of temperature on 2 different psychrophilic types of the heterotrophic nanoflagellate (HNF) Paraphysomonas imperforata isolated from the Arctic Ocean and Newfoundland. They found an increase in ingestion rates on bacteria at increasing temperatures. There is some field evidence showing a positive correlation between temperature and both bacterial production and grazing rates in different Antarctic environments (ice edge, coastal, open sea) (Leakey et al. 1996, Vaqué et al. 2002a). However, the extent to which temperature is responsible for bacterial and protist changes in biomass and activities remains unclear, since there were other factors to be considered in the latter studies such as potentially different microbial community compositions and physicochemical fields.

The aim of the present study was to test whether there is a differential response between bacterial production and protist grazing rates to short-term experi- mental warming at different locations of the Southern Ocean. This type of experimental analysis can highlight future directions of change in the biogenic fluxes of Antarctic pelagic ecosystems, in future scenarios with seasonal and local temperature changes, or at least in providing testable hypotheses for time-series records.

This study was part of the multidisciplinary project TEMPANO, whose general objective was to quantify the control exerted by temperature on metabolic processes and on the structure of planktonic communities in the Southern Ocean.

\section{MATERIALS AND METHODS}

Site and sampling. Experiments were carried out at 8 stations located in the vicinity of the Antarctic Peninsula $\left(62^{\circ} 44.52^{\prime}\right.$ to $66^{\circ} 13.16^{\prime} \mathrm{S}$, Fig. 1) on board the RV 'Hespérides' during the cruise TEMPANO from 30 November to 16 December 2002. The sampled area included several representative Antarctic waters: (1) 2 different deep-water zones (the western basin of Bransfield Strait and the Bellingshausen Sea); and (2) the eutrophic and mesotrophic coastal zone of Gerlache Strait, (for details see Pedrós-Alió et al. 2002). We visited 3 zones: the Bransfield Strait (Stns BR1 and BR2), the Gerlache Strait (Stns GE3, GE4, GE7 and GE8) and the Bellingshausen Sea (Stns BE5 and BE6) (Fig. 1). Samples for chlorophyll a (chl a) concentration, bacteria and protist abundance, bacterial heterotrophic production (BHP) and grazing experiments were taken at each station from the depth where maximum

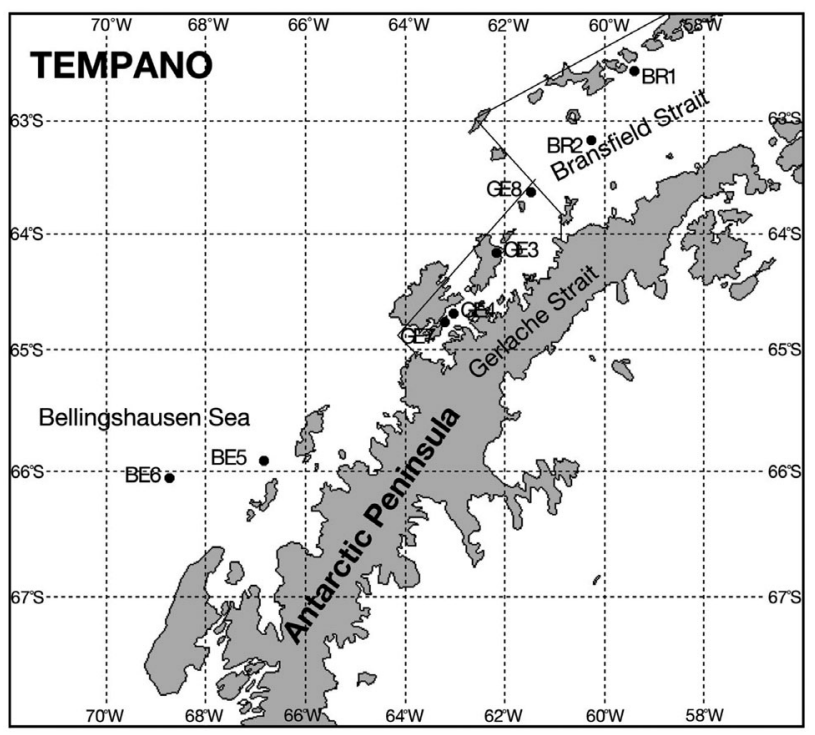

Fig. 1. Antarctic Peninsula, showing the position of the 3 zones and sampling stations for the experiments detailed in Table 1 
fluorescence was observed (deep chlorophyll maximum [DCM]) (Table 1). The exception was Stn BR1, where a DCM was not present, and samples were taken from the surface $(6 \mathrm{~m})$. Samples were collected between 10:00 and 11:00 h local time, in 121 Niskin bottles (General Oceanics) mounted on a rosette attached to a Neil Brown Mark III CTD profiler with fluorescence and light transmission sensors. Incubations started within $1 \mathrm{~h}$ after sample collection.

Chl a concentration. A volume of water between 100 and $250 \mathrm{ml}$ was filtered on GF/F filters $(25 \mathrm{~mm}$, Whatman) for fluorimetrical analysis of chl a concentration (Parsons et al. 1984). The filters were kept frozen for at least $24 \mathrm{~h}$ in the dark, followed by extraction of pigments in $90 \%$ acetone for $24 \mathrm{~h}$. Fluorescence was measured, following extraction, using a Turner Design fluorometer calibrated with pure chl a (Sigma).

Experimental design, abundance and biomass of microorganisms. At each station we collected 81 of water from the selected depths for the grazing experiments. Ten experimental 0.51 sterile plastic bags (Whirl-pak polyethylene sampling bags, Sigma) were filled with $0.5 \mathrm{l}$ of whole seawater, and 5 more bags were filled with seawater previously filtered through $0.6 \mu \mathrm{m}$ to be used as controls (no grazers). Each bag (experimental and controls) was inoculated with fluorescent-labeled bacteria (FLB $20 \%$ of ambient bacterial abundance). FLB were prepared following the procedure of Vazquez-Dominguez et al. (1999) from a strain of Brevundimonas diminuta provided by the Colección Española de Cultivos Tipo (www.cect.org).

Incubations were conducted at 5 different temperatures in NESLAB cold baths (RTE 221D) and in the dark for $48 \mathrm{~h}$. Temperatures were $-1,1,2,5^{\circ} \mathrm{C}$ and ambient, which corresponded to the in situ-measured temperature at the corresponding depth and time of sampling (Table 1). The temperature of each bath was double-checked at least twice a day with a high-precision mercury thermometer. These baths were very sta- ble $\left( \pm 0.01^{\circ} \mathrm{C}\right)$. Each temperature treatment consisted of 2 bags with whole water (duplicates) plus 1 control. Samples of $50 \mathrm{ml}$ were withdrawn from each incubation bag at time 0 (at ambient temperature) and at $48 \mathrm{~h}$ (at all incubation temperatures) using sterile pipettes, and fixed with cell-free glutaraldehyde (1\% final concentration). Within $24 \mathrm{~h}$ of sampling, aliquots were filtered, using a vacuum pump, through $0.2 \mu \mathrm{m}$ (10 ml for bacterioplankton and FLB counts) and $0.6 \mu \mathrm{m}(40 \mathrm{ml}$ for nanoflagellate counts) black polycarbonate filters, and stained with DAPI (Porter \& Feig 1980) at a final concentration of $5 \mu \mathrm{g} \mathrm{ml}^{-1}$ (Sieracki et al. 1985). Abundances were determined from epifluorescence microscopy counts (Olympus-BX40-102/E at $\times 1000$ ). Ambient bacteria were identified by their blue fluorescence when excited with UV radiation, while FLB were identified by their yellow-green fluorescence when excited with blue light. Ambient bacteria and FLB were sized by image analysis following the procedure of Massana et al. (1997). The average cell volume of FLB (0.054 \pm $0.001 \mathrm{\mu m}^{3}$ ) was larger than the average size of the ambient bacteria $\left(0.0370 \pm 0.0004 \mu^{3}\right)$. Higher bacterial volumes were obtained after $48 \mathrm{~h}$ incubation $\left(0.042 \pm 0.003 \mu \mathrm{m}^{3}\right)$. Bacterial biomass was calculated using the carbon-to-volume relationship derived by Norland (1993) from the data of Simon \& Azam (1989):

$$
\text { pg C cell }{ }^{-1}=0.12 \mathrm{pg} \times\left(\mu^{3} \operatorname{cell}^{-1}\right)^{0.7}
$$

Nanoflagellates were observed under both UV radiation and blue light. Under blue light, phototrophic nanoflagellates (identified by their red-orange fluorescence and plastidic structures) could be discriminated from colorless nanoflagellates, which were enumerated as heterotrophic. Between 100 and 150 total nanoflagellates (phototrophic and heterotrophic) per filter were counted from 3 to 4 transects of 5 to $10 \mathrm{~mm}$ each. HNF size was determined by measuring lengths and widths of all counted cells with a calibrated ocular micrometer and were grouped into 4 size classes:

Table 1. Stations, date (d/mo), depth corresponding to the deep chlorophyll maximum except for Stn BR1 (surface waters) and ambient temperature $\left(T_{\mathrm{amb}}\right)$ of samples for the warming experiments. All variables were measured at ambient temperature. $B$ : bacterial abundance; BHP: bacterial heterotrophic production; HNF: heterotrophic nanoflagellates

\begin{tabular}{|c|c|c|c|c|c|c|c|c|c|}
\hline Stn & $\begin{array}{l}\text { Date } \\
(2002)\end{array}$ & $\begin{array}{l}\text { Depth } \\
\text { (m) }\end{array}$ & $\begin{array}{l}T_{\mathrm{amb}} \\
\left({ }^{\circ} \mathrm{C}\right)\end{array}$ & $\begin{array}{c}\text { Chl a } \\
\left(\mu \mathrm{g} \mathrm{l}^{-1}\right)\end{array}$ & $\begin{array}{c}B \\
\left(\text { cells } 1^{-1}\right)\end{array}$ & $\begin{array}{c}\text { Grazing } \\
\left(\text { cells } \mathrm{l}^{-1} \mathrm{~d}^{-1}\right)\end{array}$ & $\begin{array}{c}\text { BHP } \\
\left(\text { cells } \mathrm{l}^{-1} \mathrm{~d}^{-1}\right)\end{array}$ & $\begin{array}{c}\text { HNF } \\
\left(\text { cells l-1 }^{-1}\right)\end{array}$ & $\begin{array}{l}\text { Ciliates } \\
\left(\text { cells } 1^{-1}\right)\end{array}$ \\
\hline BR1 & $30 / 11$ & 6 & -0.5 & 0.71 & $3.59 \times 10^{8}$ & $1.47 \times 10^{8}$ & $2.66 \times 10^{7}$ & $2.57 \times 10^{5}$ & 72 \\
\hline BR2 & $03 / 12$ & 43 & -0.6 & 1.45 & $5.01 \times 10^{8}$ & $1.75 \times 10^{8}$ & $2.56 \times 10^{7}$ & $1.80 \times 10^{6}$ & 119 \\
\hline GE3 & $05 / 12$ & 23 & 0.2 & 1.80 & $4.42 \times 10^{8}$ & $7.95 \times 10^{7}$ & $9.42 \times 10^{7}$ & $2.18 \times 10^{6}$ & 442 \\
\hline GE4 & $07 / 12$ & 40 & 0.4 & 0.55 & $3.00 \times 10^{8}$ & $2.15 \times 10^{7}$ & $2.52 \times 10^{7}$ & $4.70 \times 10^{5}$ & 411 \\
\hline GE7 & $14 / 12$ & 15 & -0.4 & 1.31 & $3.54 \times 10^{8}$ & $4.44 \times 10^{7}$ & $2.07 \times 10^{7}$ & $1.31 \times 10^{6}$ & 1010 \\
\hline GE8 & $16 / 12$ & 35 & 0.4 & 1.74 & $4.59 \times 10^{8}$ & $1.13 \times 10^{8}$ & $1.46 \times 10^{7}$ & $3.20 \times 10^{6}$ & 223 \\
\hline BE5 & 09/12 & 32 & -1.5 & 1.12 & $3.83 \times 10^{8}$ & $1.36 \times 10^{8}$ & $3.91 \times 10^{7}$ & $1.23 \times 10^{6}$ & 778 \\
\hline BE6 & $11 / 12$ & 34 & -1.4 & 0.75 & $5.03 \times 10^{8}$ & $3.77 \times 10^{7}$ & $2.33 \times 10^{7}$ & $9.92 \times 10^{5}$ & 608 \\
\hline
\end{tabular}


$\leq 2 \mu \mathrm{m}, 2$ to $5 \mu \mathrm{m}, 5$ to $10 \mu \mathrm{m}$ and 10 to $20 \mu \mathrm{m}$. Cell volumes were estimated assuming ellipsoid shapes, and the carbon content was estimated using a volume to carbon ratio of $0.22 \mathrm{pg} \mathrm{C} \mu^{-3}$ (Børsheim \& Bratbak 1987). In addition, 11 of water from the same station and depth was immediately fixed at the beginning of the experiment with acidic Lugol's solution (2\% final concentration) to determine ciliate abundance and composition. The fixed samples were allowed to settle in the bottle for $48 \mathrm{~h}$, and the supernatant was gently removed, leaving $\sim 200 \mathrm{ml}$. Then $100 \mathrm{ml}$ of this concentrate was further sedimented in $100 \mathrm{ml}$ chambers for at least $48 \mathrm{~h}$ before enumeration at $\times 400$ magnification using an inverted microscope (AXIOVERT35, Zeiss). For each sample, 20 to 50 ciliates were counted and sized. Cell volumes were estimated by assuming the nearest geometrical figure. Ciliates were identified to genus level when possible (Lynn \& Small 2000). Then, all ciliates were grouped into subclasses: Oligotrichia (Strombidium sp. and Tontonia sp.); Choreotrichia, naked choreotrichs (Strobilidium sp.) and loricate choreotrichs (tintinnids); and Haptoria (Mesodinium sp., Askenasia sp. and Didinium sp.). The average ciliate cell volume for each group was converted to carbon equivalents using the experimentally derived factor for Lugol's fixed marine oligotrichs, 0.2 pg C $\mu^{-3}$ (Putt \& Stoecker 1989). Tintinnid carbon was estimated using the experimentally determined factor of $0.053 \mathrm{pg} \mathrm{C} \mathrm{mm}^{-3}$ (Verity \& Langdon 1984).

Grazing rates and HNF net growth rates. Estimates of grazing rates by protists (e.g. HNF, ciliates) were based on the disappearance of FLB over time. We followed the procedure of Pace et al. (1990) as modified by Vazquez-Dominguez et al. (1999). Grazing rates were computed, using the exponential model of Salat \& Marrasé (1994), for whole water samples and controls, in order to be sure that FLB disappearance was exclusively due to grazers. Briefly, $g=-(1 / t) \times$ $\ln \left(\mathrm{FLB}_{t} / \mathrm{FLB}_{0}\right)$, where $g$ is the specific grazing rate $\mathrm{d}^{-1}$, $t$ is the incubation time, $\mathrm{FLB}_{t}$ is the abundance of FLB after $48 \mathrm{~h}$ incubation and $\mathrm{FLB}_{0}$ is the abundance of FLB at the beginning of incubations; $a=(1 / t) \times \ln \left(B_{t} / B_{0}\right)$, where $a$ is the specific bacterial net growth rate $\mathrm{d}^{-1}, t$ is the incubation time, $B_{t}$ is the bacterial abundance at $48 \mathrm{~h}$ incubation and $B_{0}$ is the bacterial abundance at the beginning of incubations; $G=(g / a) \times B_{t}$, where $G$ is total grazing (bacteria consumed $\mathrm{l}^{-1} \mathrm{~d}^{-1}$ ) and $B_{t}$ is the net bacterial production per day; and $\Delta B_{t}=B_{0} \times\left(\mathrm{e}^{a t_{1}}\right.$ $-1)$, where $t_{1}=1 \mathrm{~d}$. Grazing rates on bacteria are then given as bacteria consumed $\mathrm{l}^{-1} \mathrm{~d}^{-1}$ or converted to bio-

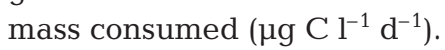

HNF net growth rates were estimated, taking into account the exponential increase or decrease in abundance or biomass between 0 and $48 \mathrm{~h}$, for all samples at all temperatures: $a_{\mathrm{HNF}}=(1 / t) \times \ln \left(\mathrm{HNF}_{t} /\right.$ $\mathrm{HNF}_{0}$ ), where $a_{\mathrm{HNF}}$ is the specific $\mathrm{HNF}$ net growth rate $\mathrm{d}^{-1}, t$ is the incubation time, $\mathrm{HNF}_{t}$ is the HNF abundance or biomass at $48 \mathrm{~h}$ incubation and $\mathrm{HNF}_{0}$ is the HNF abundance or biomass at the beginning of incubations. $\Delta \mathrm{HNF}_{t}=\mathrm{HNF}_{0} \times\left(\mathrm{e}_{\mathrm{HNF}}^{a}{ }^{t_{1}}-1\right)$, where $\Delta \mathrm{HNF}_{t}$ is the net HNF growth $\mathrm{d}^{-1}$ (cells ${ }^{-1} \mathrm{~d}^{-1}$ or $\mu \mathrm{g} \mathrm{C}$ $\mathrm{l}^{-1} \mathrm{~d}^{-1}$ ) and $t_{1}=1 \mathrm{~d}$.

Bacterial activity and BHP rates. Bacterial activity was estimated from the rate of radioactive leucine incorporation, using the method described in Kirchman (1993), with the modifications suggested by Smith \& Azam (1992). Samples of $1.2 \mathrm{ml}$ were taken at time 0 and $48 \mathrm{~h}$ from each incubated bag and were dispensed into four $2 \mathrm{ml}$ vials plus 2 trichloroacetic acid (TCA)killed control vials. Next, $48 \mu \mathrm{l}$ of a $1 \mu \mathrm{M}$ solution of ${ }^{3} \mathrm{H}$ leucine was added to the tubes providing a final concentration of $40 \mathrm{nM}$ (which was found to be saturating in these waters). Incubations were run for $4 \mathrm{~h}$ in the same thermostatic incubation baths as the experimental bags, and stopped with TCA (50\% final concentration). Next, tubes were spun in a microcentrifuge for $10 \mathrm{~min}$ at $16000 \times g$. Liquid was sucked out with a Pasteur pipette connected to a vacuum pump. Pellets were rinsed with $1.5 \mathrm{ml}$ of $5 \%$ TCA, and vortexed and spun in the microcentrifuge. Supernatant was removed and $0.5 \mathrm{ml}$ of scintillation cocktail was added. The tubes were counted within standard $20 \mathrm{ml}$ vials in a Beckman scintillation counter.

For each time point, BHP was calculated from ${ }^{3} \mathrm{H}-$ leucine incorporation (Leu) according to the equation $\mathrm{BHP}=\mathrm{Leu}\left(\mathrm{pmol} \mathrm{l}^{-1} \mathrm{~d}^{-1}\right) \times \mathrm{CF}$, where CF is the conversion factor expressed in cells $\mathrm{pmol}^{-1}$. BHP was averaged between 0 and $48 \mathrm{~h}$.

We used the semitheoretical CFs obtained for the Bransfield and Gerlache Straits $\left(11.3 \times 10^{4}\right.$ and $8.6 \times$ $10^{4}$ cells pmol $^{-1}$ respectively) and the Bellingshausen Sea $\left(11.8 \times 10^{4}\right.$ cells pmol $\left.^{-1}\right)$, as described in PedrósAlió et al. (2002), for the same time of the year. Each CF was converted to carbon, taking into account the different values of bacterial biomass obtained in the different zones and at the different incubation temperatures (Table 2). Average CFs, in carbon units, varied between $1.06 \pm 0.04 \mathrm{~kg} \mathrm{C} \mathrm{mol}^{-1}$ in the Gerlache Strait and $1.53 \pm 0.05 \mathrm{~kg} \mathrm{C} \mathrm{mol}^{-1}$ in the Bellingshausen Sea. BHP rates are given in cells $\mathrm{l}^{-1} \mathrm{~d}^{-1}$ or $\mu \mathrm{g} \mathrm{C} \mathrm{l}^{-1} \mathrm{~d}^{-1}$. The CFs we used ( 8.6 to $11.8 \times 10^{4}$ cells $\mathrm{pmol}^{-1}$ ) were similar to those reported by Ducklow et al. (1999) in the Ross Sea (average $=8 \times 10^{4}$ cells $\mathrm{pmol}^{-1}$ ) .

Terminology and data analysis. In order to identify the largest response to experimental temperatures of an activity rate (grazing rate, BHP or HNF growth) above ambient temperatures we define the maximal activity increase (MAI) as (activity rate TMAI $_{\text {- activity }}$ rate $\left._{T \mathrm{amb}}\right) /\left(T_{\mathrm{MAI}}-T_{\mathrm{amb}}\right)$, where $T_{\mathrm{MAI}}$ corresponds to the 
Table 2. Average \pm SD values of bacterial volume and biomass from different stations at ambient water temperature at time 0 (Vol $B_{0}$ and $\mathrm{BB}_{0}$, respectively) and $48 \mathrm{~h}$ ( $\mathrm{Vol} B_{48}$ and $\mathrm{BB}_{48}$, respectively). In parentheses are averages of bacterial volume and biomass for the whole range of temperatures after $48 \mathrm{~h}$ incubation

\begin{tabular}{|cccccc|}
\hline Stn & $\begin{array}{c}T_{\mathrm{amb}} \\
\left({ }^{\circ} \mathrm{C}\right)\end{array}$ & $\begin{array}{c}\text { Vol } B_{0} \\
\left(\mu \mathrm{m}^{3} \mathrm{cell}^{-1}\right)\end{array}$ & $\begin{array}{c}\mathrm{Vol} \mathrm{B}_{48} \\
\left(\mu \mathrm{m}^{3} \mathrm{cell}^{-1}\right)\end{array}$ & $\begin{array}{c}\mathrm{BB}_{0} \\
\left(\mathrm{fg} \mathrm{cell}^{-1}\right)\end{array}$ & $\begin{array}{c}\mathrm{BB}_{48} \\
\left(\mathrm{fg} \mathrm{cell}^{-1}\right)\end{array}$ \\
\hline BR1 & -0.5 & $0.033 \pm 0.000$ & $\begin{array}{c}0.042 \pm 0.000 \\
(0.044 \pm 0.001)\end{array}$ & $11.0 \pm 0.2$ & $13.1 \pm 0.2$ \\
& & & & $(13.4 \pm 0.4)$ \\
BR2 & -0.6 & $0.031 \pm 0.000$ & $\begin{array}{c}0.042 \pm 0.001 \\
(0.036 \pm 0.003)\end{array}$ & $10.6 \pm 0.2$ & $12.7 \pm 0.2$ \\
& & & & $(11.6 \pm 0.8)$ \\
GE3 & 0.2 & $0.036 \pm 0.000$ & $0.043 \pm 0.000$ & $11.6 \pm 0.0$ & $13.2 \pm 0.1$ \\
& & & $(0.043 \pm 0.001)$ & & $(13.2 \pm 0.3)$ \\
GE4 & 0.4 & $0.039 \pm 0.000$ & $0.045 \pm 0.008$ & $12.5 \pm 0.0$ & $13.6 \pm 1.7$ \\
& & & $(0.041 \pm 0.005)$ & & $(12.9 \pm 1.1)$ \\
GE7 & -0.4 & $0.040 \pm 0.000$ & $0.042 \pm 0.000$ & $12.7 \pm 0.0$ & $12.9 \pm 0.2$ \\
& & & $(0.039 \pm 0.002)$ & & $(12.4 \pm 0.4)$ \\
GE8 & 0.4 & $0.038 \pm 0.000$ & $0.043 \pm 0.003$ & $12.3 \pm 0.0$ & $13.3 \pm 0.6$ \\
& & & $(0.041 \pm 0.002)$ & & $(12.8 \pm 0.4)$ \\
BE5 & -1.5 & $0.046 \pm 0.002$ & $0.042 \pm 0.002$ & $13.9 \pm 0.4$ & $12.8 \pm 0.3)$ \\
& & & $(0.042 \pm 0.002)$ & & $(13.0 \pm 0.4)$ \\
BE6 & -1.4 & $0.034 \pm 0.000$ & $0.039 \pm 0.001$ & $11.2 \pm 0.0$ & $12.5 \pm 0.2$ \\
& & & $(0.040 \pm 0.001)$ & & $(12.7 \pm 0.2)$ \\
\hline
\end{tabular}

and BE6) showed the lowest salinities $(<34 \mathrm{psu})$ with increasing values with depth. Chl a concentration reached DCM at depths between 15 and $45 \mathrm{~m}$, except in BR1, where no DCM was observed (Table 1). The highest chl a concentration for this station was found at $6 \mathrm{~m}$ (for more details of $\mathrm{chl} a$, temperature and salinity profiles see Sala et al. 2005). Chl a concentration, bacterial and protist abundance, BHP and grazing rates at the in situ (ambient) temperature obtained at depths used in the experiments are shown in Table 1. Dominant taxa of phytoplankton were autotrophic nanoflagellates $\left(10^{5}\right.$ to $10^{6}$ cells $\left.\mathrm{l}^{-1}\right)$. Large abundances of cryptomonads were found at some stations (BR1, BR2, GE3, GE7 and GE8), followed by pennate diatoms (up to $10^{4}$ to $10^{5}$ cells $1^{-1}$ ) and dinoflagellates (up to $10^{2}$ to $10^{3}$ cells $\mathrm{l}^{-1}$ ). Details of phytoplankton data have been presented in Morán et al. (2006).

The Gerlache Strait stations showed

experimental temperature at which the maximal activity rate was obtained and $T_{\mathrm{amb}}$ is the ambient temperature. To test if activity rates at $T_{\mathrm{MAI}}$ differed significantly from activity rates at $T_{\text {amb }}$, we carried out a Wilcoxon rank-paired test. The relationships between biological variables were examined by means of correlation analyses computing Pearson pairwise statistics. When the number of observations was small we used the non-parametric Spearman rank correlation analysis. Differences between biological variables (grazing and BHP rates) and differences in HNF biomass between zones were also tested with ANOVA. Post hoc Tukey's tests were used when differences of HNF biomass between zones were found.

\section{RESULTS}

\section{Characteristics of the study area}

The study area is characterized by water temperatures always below $0.5^{\circ} \mathrm{C}$, and reaching the lowest values $\left(-1.5\right.$ and $\left.-1.4^{\circ} \mathrm{C}\right)$ at the southernmost stations in the Bellingshausen Sea (BE5 and BE6, respectively; Table 1). The water column showed rather constant values of temperature and salinity, with only minor differences between the surface and $100 \mathrm{~m}$ depth at most stations. In Stns BR1, BR2, GE3, GE4 and GE8, salinities were $>34$ psu and showed homogeneous profiles with depth, while the 3 southern stations (GE7, BE5 the highest average values of chl a $\left(1.4 \pm 0.6 \mu \mathrm{g} \mathrm{l}^{-1}\right)$, BHP $\left(3.9 \pm 3.2 \times 10^{7}\right.$ cells $\left.\mathrm{l}^{-1} \mathrm{~d}^{-1}\right)$ and HNF abundance $\left(1.8 \pm 1.1 \times 10^{6}\right.$ cells $\left.\mathrm{l}^{-1}\right)$. The Bellingshausen Sea stations showed the highest average bacterial abundance $\left(4.4 \pm 0.6 \times 10^{8}\right.$ cells $\left.{ }^{-1}\right)$, ciliate abundance $(6.9 \pm 0.8 \times$ $10^{2}$ cells $\left.\mathrm{l}^{-1}\right)$ and ciliate biomass $\left(2.3 \pm 0.2 \mu \mathrm{g} \mathrm{C}^{-1}\right)$. For the whole study area, Strombidium sp. and Strobilidium sp. dominated the ciliate assemblage. The average percentage of Strombidium sp. abundance was $64.9 \pm$ $16.5 \%$ (range $=38.0$ to $85.8 \%$ ), and biomass averaged $61.9 \pm 20.5 \%$ (range $=36.7$ to $88.2 \%$ ). The average percentages of Strobilidium sp. abundance and biomass were $20.4 \pm 17.5 \%$ (range $=0.0$ to $54.4 \%$ ) and $18.0 \pm$ $14.7 \%$ (range $=0.0$ to $43.7 \%$ ) respectively. Other ciliates, such as the mixotrophic Tontonia sp., tintinnids and haptorids, were much less abundant and not always present; thus, their contribution to abundance or biomass was very low. Finally, grazing rates $(1.6 \pm$ $0.1 \times 10^{8}$ cells $\mathrm{l}^{-1} \mathrm{~d}^{-1}$ ) were on average highest in the Bransfield Strait stations (Table 1). The average percentage of grazed bacteria with respect to the bacterial standing stock $(39.7 \pm 3.0 \%)$ and to BHP (>100\%) was also high in this zone.

\section{Temperature experiments}

Bacterial cell volumes were smaller at time 0 than at $48 \mathrm{~h}$ incubation, except at Stn BE5 (Table 2). Before incubation, bacterial cell biomass ranged between 
$10.6 \mathrm{fg} \mathrm{cell}^{-1}$ in BR2 and $13.9 \mathrm{fg} \mathrm{cell}^{-1}$ in BE5. At $48 \mathrm{~h}$ incubation at ambient temperature, bacterial cell biomass varied between $12.5 \mathrm{fg} \mathrm{cell}^{-1}$ in BE6 and $13.6 \mathrm{fg}$ cell $^{-1}$ in GE4 (Table 2). No clear pattern of increasing or decreasing bacterial volume was observed within each experiment, and the average cell volume for the whole range of temperatures after $48 \mathrm{~h}$ incubation was similar to that of the ambient temperature treatment (Table 2). An ANOVA showed significant differences when comparing the whole dataset for cell volume or biomass at ambient temperature between times 0 and $48 \mathrm{~h}(\mathrm{n}=32, F=9.9, \mathrm{p}=0.003)$, or between time 0 and
$48 \mathrm{~h}$ incubations considering the whole range of temperatures ( $\mathrm{n}=160, F=28.9, \mathrm{p}<0.0001)$.

BHP and grazing rates are shown in Fig. 2. Disappearance of FLB in controls was negligible. At ambient temperature, statistically significant differences between these 2 variables were detected only in the Bransfield Strait ( $\mathrm{n}=4, F=27.9, \mathrm{p}=0.023$ ). However, when the highest experimental temperatures (2 and $5^{\circ} \mathrm{C}$ ) were considered, grazing rates were lower than BHP in the Gerlache Strait (except at GE8) ( $\mathrm{n}=24, F=$ $4.2, \mathrm{p}=0.05)$, higher than BHP rates in the Bransfield Strait (n = 12, F = 32.2, $\mathrm{p}<0.0001$ ) and similar to BHP
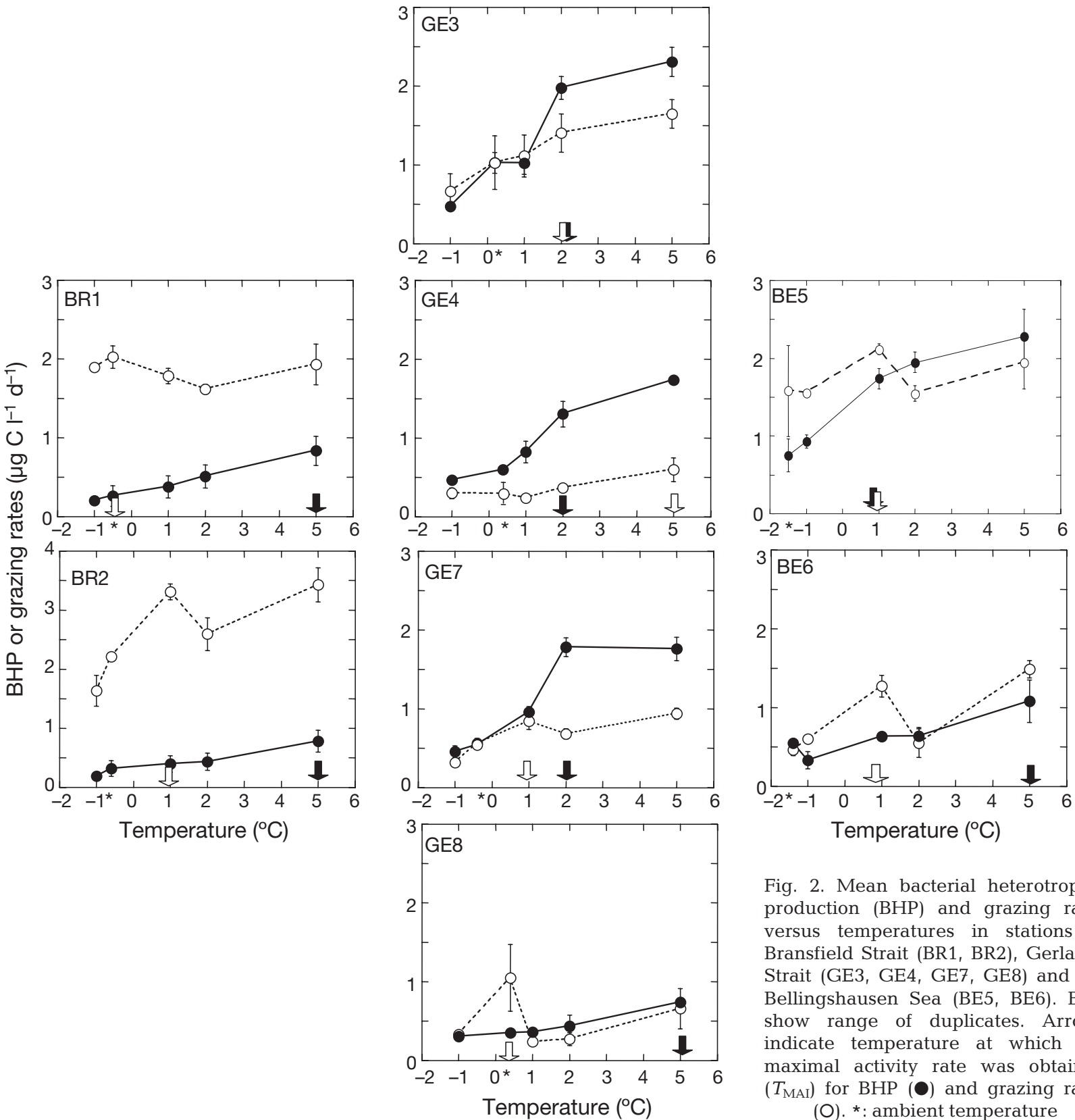

Fig. 2. Mean bacterial heterotrophic production (BHP) and grazing rates versus temperatures in stations of Bransfield Strait (BR1, BR2), Gerlache Strait (GE3, GE4, GE7, GE8) and the Bellingshausen Sea (BE5, BE6). Bars show range of duplicates. Arrows indicate temperature at which the maximal activity rate was obtained $\left(T_{\mathrm{MAI}}\right)$ for $\mathrm{BHP}(\bullet)$ and grazing rates (O). * : ambient temperature 
in the Bellingshausen Sea ( $\mathrm{n}=16, F=0.6, \mathrm{p}=0.548$ ) (Fig. 2). The average percentage of grazed bacteria to BHP at the highest experimental temperatures was low $(56 \pm 19 \%)$ in the Gerlache Strait, high $(395 \pm 137 \%)$ in the Bransfield Strait and approximately balanced (97 \pm $24 \%$ ) in the Bellingshausen Sea (Fig. 2).

Maximal grazing rates occurred at $T_{\mathrm{MAI}} \leq 2^{\circ} \mathrm{C}$, except at GE4 $\left(5^{\circ} \mathrm{C}\right)$. In 2 stations, BR1 and GE8, $\mathrm{T}_{\mathrm{MAI}}$ was identical to ambient temperature (Table 3). Note that for Stn BE5 (Fig. 2), the grazing rate at $1^{\circ} \mathrm{C}$ was not significantly different from that obtained at $-1.5^{\circ} \mathrm{C}$. However, due to variability between duplicates at $-1.5^{\circ} \mathrm{C}$ and the consistency of the 2 values at $1{ }^{\circ} \mathrm{C}$, we decided to consider the latter value as the maximal grazing rate. Maximal BHP rates occurred at $T_{\mathrm{MAI}} \geq 2^{\circ} \mathrm{C}$, except in 1 station in the Bellingshausen Sea (BE5), and were higher than for grazing rates on 5 occasions, similar in 2 and lower in 1 (Fig. 2, Table 3).

Both activity rates (grazing and BHP) determined at $T_{\text {MAI }}$ were significantly different from those at ambient temperatures (Wilcoxon rank sign test, $\mathrm{n}=24, \mathrm{p}<$ 0.001 for grazing rates, and $\mathrm{n}=32, \mathrm{p}<0.0001$ for BHP).

Biomass of ambient HNF was not different between zones ( $\mathrm{n}=16, F=1.1, \mathrm{p}>0.05)$. In incubations carried out at ambient temperature, HNF biomass at $48 \mathrm{~h}$ was not significantly different from that at the beginning of the experiments $(\mathrm{n}=32, F=1.5, \mathrm{p}>0.05)$. In contrast, considering only temperatures above ambient, average HNF biomass values were similar between the Bellingshausen Sea and the Gerlache Strait, and both were higher than in the Bransfield Strait. Thus, an ANOVA showed significant differences between the 3 zones considered ( $\mathrm{n}=52, F=4.1, \mathrm{p}=0.022)$, and a post hoc Tukey's test revealed that these differences were mainly due to differences in HNF biomass between the Bransfield Strait $(\mathrm{n}=12)$ and the Bellingshausen Sea waters $(\mathrm{n}=16, \mathrm{p}=0.019)$. The largest increments in HNF biomass after $48 \mathrm{~h}$ incubations were found at temperatures between 1 and $2^{\circ} \mathrm{C}$ (Table 3). Net growth rates of $\mathrm{HNF}$ biomass at $T_{\mathrm{MAI}}$ differed significantly from those at ambient temperature $(n=28, p<0.0001$, Wilcoxon signed rank test), except in GE8, where ambient temperature was $0.4^{\circ} \mathrm{C}$ and the maximal increase in $\mathrm{HNF}$ growth rate occurred at $-1.0^{\circ} \mathrm{C}$.

In the Bransfield Strait, HNF $\leq 5 \mu \mathrm{m}$ dominated HNF biomass at the beginning and at the end of the experiments, at all temperatures assayed (Fig. 3, where only 3 selected stations representative of the study area are shown). Conversely, in the Gerlache Strait and Bellingshausen Sea stations, HNF $>5 \mu \mathrm{m}$ became dominant at the end of the incubations at all temperatures assayed (Fig. 3). Using values of HNF at the end of the experiments, a significant negative correlation was found between grazing rates and the percentage of biomass of HNF $>5 \mu \mathrm{m}(\mathrm{n}=38, \mathrm{r}=$ $-0.557, \mathrm{p}<0.001$ ), and a positive correlation between grazing rates and the percentage of biomass of HNF $\leq 5 \mu \mathrm{m}(\mathrm{n}=38, \mathrm{r}=0.318, \mathrm{p}=0.050)$. This indicates that HNF $\leq 5 \mu \mathrm{m}$ were likely responsible for bacterial grazing rates. In order to illustrate this conclusion, we carried out a correlation between the average values of grazing rates and the biomass of HNF $\leq 5 \mu \mathrm{m}$ at all different temperatures for each station. With the exception of Stn BR1, these 2 variables covaried (Spearman rank correlation, $\mathrm{r}=0.713, \mathrm{n}=7, \mathrm{p}=0.01$, Fig. 4).

Differences between $T_{\mathrm{MAI}}$ and $T_{\mathrm{amb}}(\Delta T)$ are shown in Table 3. It is interesting to observe than in 2 cases (BR1 and GE8) there were no increases in grazing rates above ambient temperature. In contrast, BHP and HNF biomass values always increased at temperatures above the ambient. The exception was found in GE8, where the maximal increase in HNF was observed below the ambient temperature $\left(-1^{\circ} \mathrm{C}\right)$.

Finally, MAIs for grazing rates and BHP are plotted against each other in Fig. 5. Contrary to our expectations, maximal increases in grazing rates did not follow maximal increases in BHP rates. In most cases, $\mathrm{MAI}_{\mathrm{BHP}}$ was higher than MAI $_{\text {grazing, }}$ but in 2 stations it was the other way around.

Table 3. Temperature at which the maximal activity increase was obtained ( $\left.T_{\mathrm{MAI}}\right)$ for grazing rates, bacterial heterotrophic production (BHP) and heterotrophic nanoflagellate (HNF) growth, and difference between $T_{\mathrm{MAI}}$ and $T_{\mathrm{amb}}(\Delta T)$ for the different stations

\begin{tabular}{|c|c|c|c|c|c|c|c|c|}
\hline \multirow[t]{2}{*}{ Stn } & \multirow[t]{2}{*}{ Depth (m) } & \multirow[t]{2}{*}{$T_{\mathrm{amb}}\left({ }^{\circ} \mathrm{C}\right)$} & \multicolumn{3}{|c|}{$-T_{\mathrm{MSI}}\left({ }^{\circ} \mathrm{C}\right)-$} & \multicolumn{3}{|c|}{$-\Delta T\left({ }^{\circ} \mathrm{C}\right)-$} \\
\hline & & & Grazing & BHP & HNF & Grazing & BHP & HNF \\
\hline BR1 & 6 & -0.5 & -0.5 & 5.0 & 1.0 & 0 & 5.5 & 1.5 \\
\hline BR2 & 42 & -0.6 & 1.0 & 5.0 & 1.0 & 1.6 & 5.6 & 1.6 \\
\hline GE3 & 23 & 0.2 & 2.0 & 2.0 & 1.0 & 1.8 & 1.8 & 0.8 \\
\hline GE4 & 40 & 0.4 & 5.0 & 2.0 & 1.0 & 4.6 & 1.6 & 0.6 \\
\hline GE7 & 15 & -0.4 & 1.0 & 2.0 & 2.0 & 1.4 & 2.4 & 2.4 \\
\hline GE8 & 35 & 0.4 & 0.4 & 5.0 & -1.0 & 0 & 4.6 & -1.4 \\
\hline BE5 & 32 & -1.5 & 1.0 & 1.0 & 2.0 & 2.5 & 2.5 & 3.5 \\
\hline BE6 & 34 & -1.4 & 1.0 & 5.0 & 1.0 & 2.4 & 6.4 & 2.4 \\
\hline
\end{tabular}




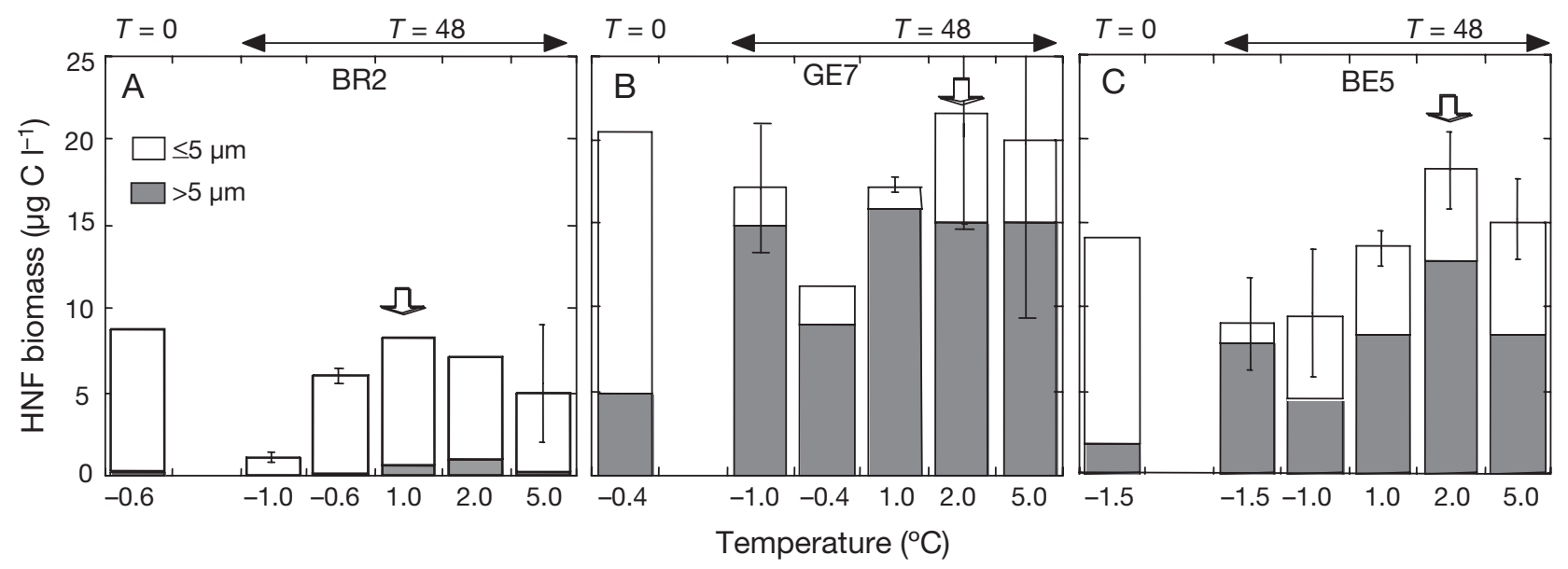

Fig. 3. Mean heterotrophic nanoflagellate (HNF) biomass ( $\leq 5 \mu \mathrm{m}$ and $>5 \mu \mathrm{m}$ size classes) at ambient temperature at the start of incubation and after $48 \mathrm{~h}$ incubations at different temperatures in selected stations representative of the 3 sampled zones. (A) Bransfield Strait (BR2), (B) Gerlache Strait (GE7) and (C) Bellingshausen Sea (BE5). Bars show range of duplicates. When values were very close bars are not visible. Arrows indicate $T_{\mathrm{MAI}}$ for HNF growth rates

\section{DISCUSSION}

\section{Methodological constraints}

All methods to estimate complex ecosystem variables such as BHP and grazing rates on bacteria are based on a series of assumptions and uncertainties. For BHP rates, the incorporation of radioactive leucine into protein is considered a standard method that has been addressed in Kirchman et al. (1985), Simon \& Azam (1989), Kirchman (1993) and Kirchman \& Ducklow (1993). For grazing on bacteria, one can refer to Pace et al. (1990), Monger \& Landry (1992), Vaqué et al. (1994), Landry (1994), Leakey et al. (1996), Christoffersen et al. (1997) and Vaqué et al. (2002a,b), among others. These authors used different types of bacterial surrogates (e.g. minicells, FLB, immunofluorescencelabeled bacteria) and different incubation times. The bulk disappearance of FLB as tracers of natural bacteria used in the present study is, in our view, the best option in studies where the dynamics of the whole bacterial assemblage is targeted. In addition, it introduces the least possible water manipulation, which is a potential source of artifacts. We used this method despite its potential problems, broadly discussed in the above-mentioned studies, because they are state of the art. In order to compensate for bacterial growth owing to confinement in the experimental bags, we measured BHP rates in the same incubation bags as those used for grazing estimates, both at time 0 and at $48 \mathrm{~h}$; we then averaged these values. We also corrected for changes in bacterial cell volume over time, which can vary due to confinement (Ferguson et al. 1984) and due to different incubation temperatures (Hagström \& Larsson 1984). These changes in bacterial cell volume would affect the CFs used. Measurements of cell volume and estimates of carbon:volume ratio $\mathrm{CFs}$ have intrinsic variability. Image analysis is the most widely used method to size bacteria (Leakey et al. 1996, Sherr et al. 1997, Bird \& Karl 1999). Uncertainty increases when estimating carbon biomass, since there is a range of CFs using either fixed carbon per cell factors (Laurion et al. 1995, Leakey et al. 1996, Bird \& Karl 1999) or carbon per volume factors (Becquevort 1997, Sherr et al. 1997, Riedel et al. 2007). In the present study, we calculated carbon cell values from cell sizes following the relationship of Norland (1993).

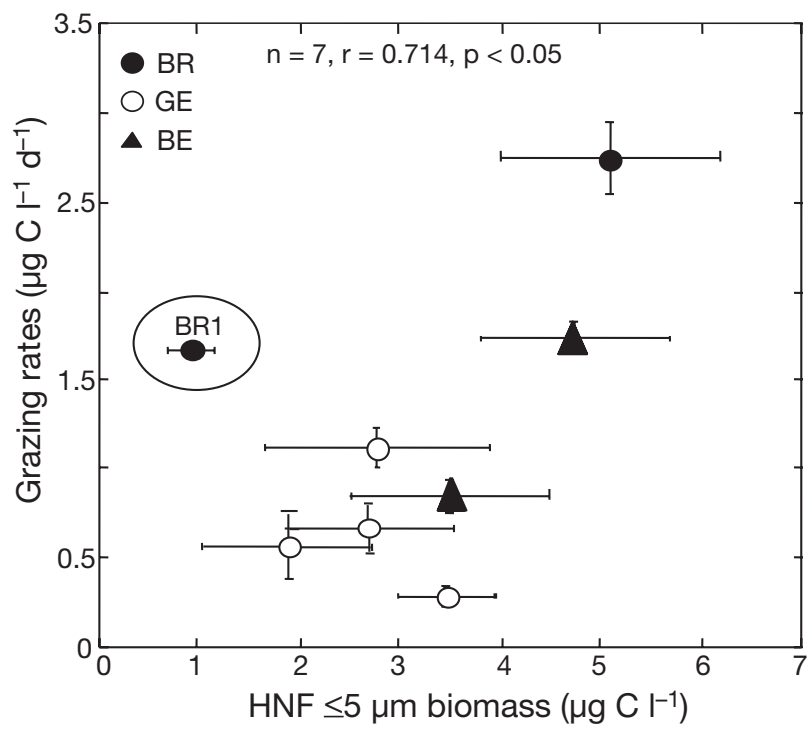

Fig. 4. Relationship between averaged grazing rates and averaged HNF $(\leq 5 \mu \mathrm{m})$ biomass for all the temperature ranges, including ambient, at $48 \mathrm{~h}$ incubation. Each point is the average \pm SD of 5 values. Circle: outlier value (see text). BE: Bellingshausen Sea; BR: Bransfield Strait; GE: Gerlache Strait 


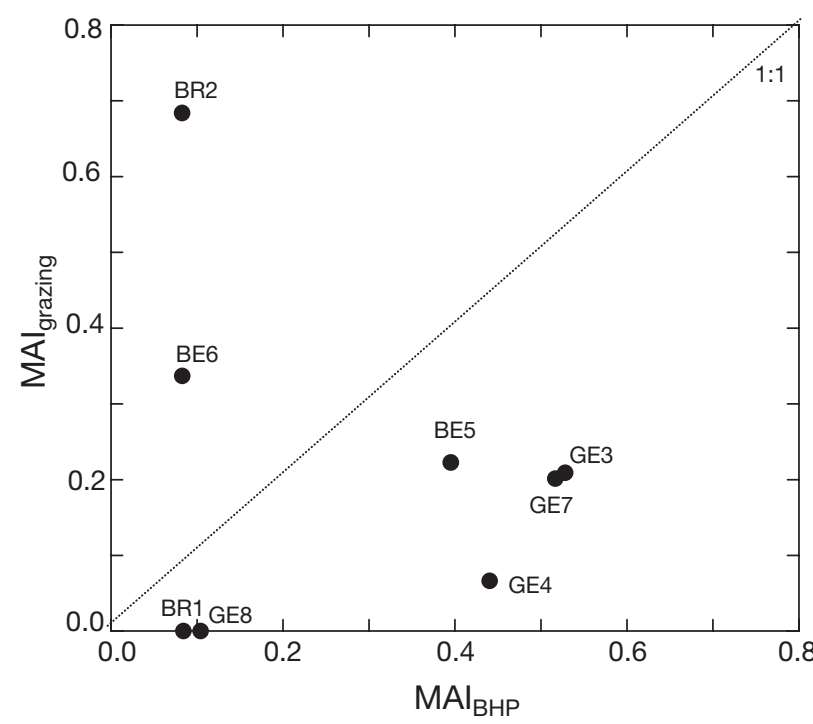

Fig. 5. Relationship between maximal activity increase (MAI) for grazing (MAI grazing $)$ and BHP $\left(\mathrm{MAI}_{\mathrm{BHP}}\right)$. MAI = (activity rate $_{T M A I}-$ activity rate Tamb $) /\left(T_{\mathrm{MAI}}-T_{\mathrm{amb}}\right) .1: 1$ Line is indicated

In summary, the main drawback is related to the measurement of rates of long-term incubations that may cause changes in the in situ microbial community structure and activity. Indeed, we estimated all variables considered (BHP, grazing rates and changes in HNF biomass) over $48 \mathrm{~h}$, and one aspect holds true: compared with grazing on bacteria, bacterial production always showed higher responses to temperature increases.

\section{Microbial abundance and BHP rates}

Chl $a$ concentration at the depths sampled (mean $=$ $1.2 \pm 0.2 \mu \mathrm{g} \mathrm{l}^{-1}$ ) was not as high as expected for the time of year, compared to higher values found in similar zones and periods during a previous cruise (FRUELA95, Vaqué et al. 2002b). These low values probably indicated that we were in the initial stages of bloom development. Comparisons of bacterial and HNF abundances among the Bransfield and Gerlache Straits and the Bellingshausen Sea (Bird \& Karl 1999, Vaqué et al. 2002b, present study) gave more similar results than comparisons between other polar sites (Table 4). In the present study, we observed that maximal values of microbial abundances are much lower than maximal values found in other sites during other cruises, except for Arctic data collected in Franklin Bay, Canada, in winter. BHP rates varied between $0.3 \mu \mathrm{g} \mathrm{C}^{-1} \mathrm{~d}^{-1}$ at $-0.5^{\circ} \mathrm{C}$ (Bransfield Strait, BR1) and $1.0 \mu \mathrm{g} \mathrm{C}^{-1} \mathrm{~d}^{-1}$ at $0.2^{\circ} \mathrm{C}$ (Gerlache Strait, GE3). These values were also at the low end compared to those obtained by, for example, Bird \& Karl (1999) and
Pedrós-Alió et al. (2002) in Antarctic waters, and Sherr et al. (1997) in the Arctic Ocean. This low heterotrophic microbial abundance and activity was probably a consequence of the fact that primary producers were at the initial stages of bloom development, as indicated by the chl a concentration (Table 1).

\section{Effect of temperature on microbial activities}

We found different responses of BHP to temperature increases between stations of the same zones (Fig. 2, Table 3). For BHP, $T_{\mathrm{MAI}}$ was at $5^{\circ} \mathrm{C}$ in 4 stations (BR1, $\mathrm{BR} 2, \mathrm{GE} 8$ and BE6), at $2^{\circ} \mathrm{C}$ in 3 stations (GE3, GE4 and GE7) and at $1^{\circ} \mathrm{C}$ only in BE5. These results are in agreement with the large variability of bacterial responses to temperature observed by Pedrós-Alió et al. (2002) in December in the same area, for a very short temperature range analyzed, with $Q_{10}$ values ranging from 2 to 25. Ducklow et al. (1999) found that bacterial growth was not stimulated after several days incubation in seawater cultures at $2^{\circ} \mathrm{C}$ compared to $-2^{\circ} \mathrm{C}$. Such variable responses of BHP to temperature could be a consequence of different initial microbial communities (prokaryotes and eukaryotes), experimental incubation time, availability of dissolved organic carbon and grazing rates.

We had expected that grazing would increase in parallel with bacterial production for the whole experimental temperature range. However, we have compared the differential response of MAI for grazing rates and $\mathrm{PHB}$ at the corresponding $T_{\mathrm{MAI}}$ (Fig. 5). Taking into account the 1:1 line, $\mathrm{MAI}_{\text {grazing }}$ was higher than $\mathrm{MAI}_{\mathrm{PHB}}$ in only 2 cases. We also found that $T_{\mathrm{MAI}}$ for grazing rates was mostly lower than and sometimes equal to $T_{\mathrm{MAI}}$ for BHP, except at GE4 (Table 3), and in 2 cases (BR1 and GE8), $T_{\text {MAI }}$ for grazing rates coincided with the ambient temperature (Table 3). The important message is that grazing rate increases with temperature are always modest. This is most likely explained by protist assemblages well adapted to these low temperatures, or by the grazing rates on bacteria being buffered by trophic interactions between HNF size classes (Sherr \& Sherr 2002). This likelihood could be linked to changes in HNF communities with different growth and grazing rates occurring during incubations. Thus, at time 0 of the experiments, the community of HNF was dominated by HNF $\leq 5 \mu \mathrm{m}$, presumably bacterivores (Leakey et al. 1996, Sherr et al. 1997, Bird \& Karl 1999). During the $48 \mathrm{~h}$ incubation, the net growth of HNF biomass at ambient temperature was always negative (Fig. 3), indicating that HNF were topdown controlled by microzooplankton (Vaqué et al. 2004). In addition, data shown in Fig. 3 suggest a cascading effect, where the increase of the HNF $>5 \mu \mathrm{m}$ 
Table 4. Range of bacterial $(B)$ and heterotrophic nanoflagellate (HNF) abundance, bacterial heterotrophic production $\left(\mathrm{BHP},{ }^{3} \mathrm{H}-\right.$ leucine) and temperature values recorded in different polar waters at different seasons. nd: not detectable; -: no data; BSO-WSC: waters of Bellingshausen Sea origin and Weddell Scotia Confluence

\begin{tabular}{|c|c|c|c|c|c|c|}
\hline Location & Depth (m) & $B\left(\times 10^{8} 1^{-1}\right)$ & $\operatorname{HNF}\left(\times 10^{6} l^{-1}\right)$ & $\mathrm{BHP}\left(\mu \mathrm{g} \mathrm{C}^{-1} \mathrm{l}^{-1} \mathrm{~d}^{-1}\right)$ & Temp $\left({ }^{\circ} \mathrm{C}\right)$ & Source \\
\hline \multicolumn{6}{|l|}{ Ice edge } & \multirow{2}{*}{$\begin{array}{l}\text { Putt et al. (1991), } \\
\text { Moisan et al. (1991) }\end{array}$} \\
\hline McMurdo Sound & 25 & $1.0-7.0$ & $1.0-12.0$ & - & $\begin{array}{c}-1.0-0.4 \\
\text { (spring-summer) }\end{array}$ & \\
\hline \multicolumn{6}{|l|}{ East Antarctica } & \multirow[t]{2}{*}{ Leakey et al. (1996) } \\
\hline Prydz Bay & 5 & $2.1-8.3$ & $1.6-4.2$ & $8.0-14.0^{\mathrm{a}}$ & $\begin{array}{l}-1.4-(-0.4) \\
\text { (summer) }\end{array}$ & \\
\hline \multicolumn{6}{|l|}{ Atlantic Sector } & \multirow[t]{2}{*}{ Becquevort (1997) } \\
\hline Southern Ocean & 20 & $4.3-6.4$ & $0.3-1.4$ & $1.0-42.0^{\mathrm{b}}$ & $\begin{array}{c}- \\
\text { (spring) }\end{array}$ & \\
\hline \multicolumn{6}{|l|}{ Antarctic Peninsula } & \multirow[t]{2}{*}{ Bird \& Karl (1999) } \\
\hline Gerlache Strait & Surface & $0.9-7.5$ & $0.5-2.6$ & $0.1-10.6$ & $\begin{array}{c}-0.5-0.8 \\
\text { (spring) }\end{array}$ & \\
\hline \multicolumn{6}{|l|}{ Antarctic Peninsula } & \multirow[t]{5}{*}{ Vaqué et al. (2002a) } \\
\hline Ice edge & $0-60$ & $0.7-10.0$ & nd-1.3 & $<0.1-0.9$ & $-1.7-(-0.1)$ & \\
\hline Weddell Sea & $0-60$ & $0.7-11.5$ & $0.3-5.6$ & $<0.1-4.9$ & $-0.5-0.7$ & \\
\hline Front & 15 & $1.5-7.6$ & $0.8-9.7$ & $<0.1-1.4$ & $-1.1-1.7$ & \\
\hline BSO-WSC & $0-70$ & $1.4-6.2$ & $0.2-11.8$ & $<0.1-2.8$ & $\begin{array}{l}0.04-2.4 \\
\text { (summer) }\end{array}$ & \\
\hline \multicolumn{6}{|l|}{ Antarctic Peninsula } & \multirow{4}{*}{$\begin{array}{l}\text { Vaqué et al. (2002b) } \\
\text { Pedrós-Alió et al. (2002) }\end{array}$} \\
\hline Bellingshausen & $20-30$ & $3.4-3.5$ & $0.3-2.2$ & $0.1-3.3$ & $-0.06-2.4$ & \\
\hline Bransfield Strait & $5-8$ & $3.6-6.9$ & $0.5-0.9$ & $0.1-2.6$ & $0-0.2$ & \\
\hline Gerlache Strait & $5-8$ & $2.5-7.2$ & $0.4-2.1$ & $0.2-3.1$ & $\begin{array}{c}-1.2-0.4 \\
\text { (spring-summer) }\end{array}$ & \\
\hline \multicolumn{7}{|l|}{ Canadian Arctic } \\
\hline Resolute Passage (sea ice) & $0.4^{\mathrm{c}}$ & $1.0-10.0$ & $0.2-35.0$ & - & $\begin{array}{c}- \\
\text { (spring) }\end{array}$ & Laurion et al. (1995) \\
\hline Arctic Ocean & $50-75^{\mathrm{d}}$ & $3.8-11.7$ & $0.2-1.9$ & $1.0-3.9$ & $\begin{array}{c}- \\
\text { (summer) }\end{array}$ & Sherr et al. (1997) \\
\hline \multicolumn{6}{|l|}{ Canadian Arctic } & \multirow[t]{2}{*}{ Vaqué et al. (2008) } \\
\hline Franklin Bay & 3 & $1.5-5.2$ & $0.2-0.6$ & $0.03-0.2$ & $\begin{array}{c}-1.7-(-1.5) \\
\text { (winter-spring) }\end{array}$ & \\
\hline \multicolumn{6}{|l|}{ Antarctic Peninsula } & \multirow[t]{4}{*}{ Present study } \\
\hline Bellingshausen & $32-34$ & $3.8-5.0$ & $1.0-1.2$ & $0.6-0.8$ & $-1.5-(-1.4)$ & \\
\hline Bransfield Strait & $6-43$ & $3.6-5.1$ & $0.3-1.8$ & $0.3-0.5$ & $-0.5-(-0.6)$ & \\
\hline Gerlache Strait & $15-40$ & $3.0-4.6$ & $0.5-3.2$ & $0.4-1.0$ & $\begin{array}{c}-0.4-0.4 \\
\text { (spring) }\end{array}$ & \\
\hline
\end{tabular}

fraction at all temperatures was in contrast with the dynamics of the smaller HNF (except for Bransfield Strait, where the HNF $\leq 5 \mu \mathrm{m}$ dominated). These results and the low abundance of ciliates detected (Table 1) suggest that ciliates were not playing an important role as predators on HNF $>5 \mu \mathrm{m}$. Calbet et al. (2001) found microbial cascade effects in temperate waters using fractionation experiments. By filtering samples through several pore-size filters, they showed that bacterial growth increased when cells $>5 \mu \mathrm{m}$ were present. Presumably, these protists were reducing abundances of $<5 \mu \mathrm{m}$ bacterial predators. Other factors, such as non-saturating bacterial concentration and changes in bacterial diversity produced by changes in temperature and/or viral infection, that in turn was responsible for bacterial lysis (Steward et al. 1996,
Guixa-Boixereu et al. 2002), promoting the release of dissolved organic carbon and changes in the bacterial community structure (Weinbauer 2004), could contribute to shifting prey for HNF.

\section{CONCLUSIONS}

Small changes in temperature differentially affected the activity of microbial assemblages. In most cases, compared with grazing rates, BHP showed a stronger response to temperature. The present study shows that maximal BHP rates were obtained at higher temperatures than were maximal grazing rates on bacteria. On the one hand, this indicates that the protists are better adapted than the bacteria to the very low ambient tem- 
peratures, or that trophic cascade effects on HNF $\leq 5 \mu \mathrm{m}$ buffered the grazing activity. On the other hand, this suggests that bacterial assemblages have a higher potential for activity increases than do protists if temperatures were to increase above ambient. This differential response would result in changes in bacterial community diversity and shifts in bacterial carbon fluxes. The response to temperature increases of a complex system that includes a variety of non-linear metabolic responses, individual behavior and food web interactions would have been impossible from simple $Q_{10}$ relationships. The knowledge gained from the study will be useful in developing some testable hypotheses, such as those concerning the uncoupling of bacterial production from bacterial grazing, with implications for carbon fluxes (e.g. high bacterial respiration instead of carbon fluxes to higher trophic levels) for the Southern Ocean, in future or present scenarios that contemplate local and seasonal changes in temperature. The temperature increases assayed here are in the range of long-term oceanic temperature changes for the Southern Ocean, and may give insight into the variability of present and future biogeochemical fluxes in polar waters. Other factors such as acclimation of microbial assemblages or replacement of taxa optimized for growth at different conditions (e.g. Karl et al. 2001) will also need to be taken into account.

Acknowledgements. This study was supported by the Spanish MCyT grant REN2001-0588/ANT to D.V. We thank the scientists, scientific support staff and crew of the RV 'Hespérides' for their help during the enjoyable TEMPANO cruise. We are particularly grateful to A. Sabata, L. Font, L. Albert and R. Massana for helping in nanoflagellate and ciliate counts. Finally, we thank 3 anonymous reviewers for their thoughtful comments that have contributed to the improvement of the manuscript.

\section{LITERATURE CITED}

Becquevort S (1997) Nanoprotozooplankton in the Atlantic sector of the Southern Ocean during early spring: biomass and feeding activities. Deep-Sea Res II 44:355-373

Bindoff NL, Willebrand J, Artale V, Cazenave A and others (2007) Observations: ocean climate change and sea level. In: Solomon S, Qin D, Manning M, Marquis M, Averyt K, Tignor MMB, Miller HL, Chen Z (eds) Climate change 2007: the physical science basis. Contribution of Working Group I to the Fourth Assessment Report of the Intergovernmental Panel on Climate Change. Cambridge University Press, Cambridge, p 385-432

Bird DF, Karl DM (1999) Uncoupling of bacteria and phytoplankton during austral spring bloom in Gerlache Strait, Antarctic Peninsula. Aquat Microb Ecol 19:13-27

> Børsheim KY, Bratbak G (1987) Cell volume to cell carbon conversion factors for a bacterivorous Monas sp. enriched from seawater. Mar Ecol Prog Ser 36:171-175

Calbet A, Landry MR, Nunnery S (2001) Bacteria-flagellate interactions in the microbial food web of the oligotrophic subtropical North Pacific. Aquat Microb Ecol 23:283-292

> Choi JW, Peters F (1992) Effects on temperature in two psychrophilic ecotypes of a heterotrophic nanoflagellate, Paraphysomonas imperforata. Appl Environ Microbiol 58:593-599

Christoffersen K, Nybroe Ø, Jürgens K, Hansen M (1997) Measurement of bacterivory by heterotrophic nanoflagellates using inmunofluorescence labelling of ingested cells. Aquat Microb Ecol 13:127-134

> Ducklow H, Carlson C, Smith W (1999) Bacterial growth in experimental plankton assemblages and seawater cultures from the Phaeocystis antarctica bloom in the Ross Sea, Antarctica. Aquat Microb Ecol 19:215-227

> Ferguson RL, Buckley EN, Palumbo AV (1984) Response of marine bacterioplankton to differential filtration and confinement. Appl Environ Microbiol 47:49-55

Guixa-Boixereu N, Vaqué D, Gasol JM, Sánchez-Cámara J, Pedrós-Alió C (2002) Viral distribution and activity in Antarctic waters. Deep-Sea Res II 49:827-845

Hagström Å, Larsson U (1984) Diel and seasonal variation in growth rates of pelagic bacteria. In: Hobbie $\mathrm{JH}$, Williams PJLeB (eds) Heterotrophic activity in the sea. Plenum Press, New York

Harder W, Veldkamp H (1971) Competition of marine psychrophilic bacteria at low temperatures. Antonie Leeuwenhoek 37:51-63

> Hoppe H-G, Breithaupt P, Walther K, Koppe R, Bleck S, Sommer U, Jürgens K (2008) Climate warming in winter affects the coupling between phytoplankton and bacteria during the spring bloom: a mesocosm study. Aquat Microb Ecol 51:105-115

> Karl DM, Bidigare RR, Letelier RM (2001) Long-term changes in plankton community structure and productivity in the North Pacific Subtropical Gyre: the domain shift hypothesis. Deep-Sea Res II 48:1449-1470

Kirchman D, K'nees E, Hodson R (1985) Leucine incorporation and its potential as a measure of protein synthesis by bacteria in natural aquatic systems. Appl Environ Microbiol 49:599-607

Kirchman DL (1993) Leucine incorporation as a measure of biomass production by heterotrophic bacteria. In: Kemp PF, Sherr BF, Sherr EB, Cole JJ (eds) Handbook of methods in aquatic microbial ecology. Lewis Publishers, Boca Raton, FL, p 509-512

Kirchman DL, Ducklow HW (1993) Estimating conversion factors for the thymidine and leucine methods for measuring bacterial production. In: Kemp PF, Sherr BF, Sherr EB, Cole JJ (eds) Handbook of methods in aquatic microbial ecology. Lewis Publishers, Boca Raton, FL, p 513-517

Landry MR (1994) Methods and controls of measuring the grazing impact of planktonic protist. Mar Microb Food Webs 8:37-57

> Laurion I, Demers S, Vézina AF (1995) The microbial food web associated with the ice algal assemblage: biomass and bacterivory of nanoflagellate protozoans in Resolute Passage (High Canadian Arctic). Mar Ecol Prog Ser 120: $77-87$

- Leakey RJG, Archer SD, Grey J (1996) Microbial dynamics in coastal waters of East Antarctica: bacterial production and nanoflagellate bacterivory. Mar Ecol Prog Ser 142:3-17

Longhurst A (1998) Ecological geography of the sea. Academic Press, San Diego, CA

Lynn DH, Small EB (2000) Phylum Ciliophora. In: Lee JJ, Leedale GF, Bradbury P (eds) An illustrated guide to the protozoa. Allen Press, Lawrence, KS, p 371-656 
Massana R, Gasol JM, Bjørnsen PK, Blackburn N and others (1997) Measurement of bacterial size via image analysis of epifluorescence preparations: description of an inexpensive system and solutions to some of the most common problems. Sci Mar 61:397-407

Meredith MP, King JC (2005) Rapid climate change in the ocean west of the Antarctic Peninsula during the second half of the 20th century. Geophys Res Lett 32:L19604

Moisan T, Putt M, Stoecker D (1991) Bacterivory in McMurdo Sound. 2. Information from size-fractionation experiments. Antarct J US 26:141-142

Monger BC, Landry MR (1992) Size-selective grazing by heterotrophic nanoflagellates: an analysis using live-stained bacteria and dual-beam flow cytometry. Arch Hydrobiol Beih 37:173-185

Morán XAG, Sebastián M, Pedrós-Alió C, Estrada M (2006) Response of Southern Ocean phytoplankton and bacterioplankton production to short-term experimental warming. Limnol Oceanogr 51:1791-1800

Morita RY (1975) Psychrophilic bacteria. Bacteriol Rev 39: $144-167$

Norland S (1993) The relationship between biomass and volume of bacteria. In: Kemp PF, Sherr BF, Sherr EB, Cole JJ (eds) Handbook of methods in aquatic microbial ecology. Lewis Publishers, Boca Raton, FL, p 303-307

Pace ML, McManus GB, Findlay SEG (1990) Planktonic community structure determines the fate of bacterial production in a temperate lake. Limnol Oceanogr 35:795-808

Parsons TR, Maita Y, Lalli CM (1984) A manual of chemical and biological methods for seawater analysis. Pergamon Press, Oxford

Pedrós-Alió C, Vaqué D, Guixa-Boixereu N, Gasol JM (2002) Prokaryotic plankton biomass and heterotrophic production in western Antarctic waters during the 1995-1996 austral summer. Deep-Sea Res II 49:805-825

Pomeroy LR, Wiebe WJ (2001) Temperature and substrates as interactive limiting factors for marine heterotrophic bacteria. Aquat Microb Ecol 23:187-204

Pomeroy LR, Wiebe WJ, Deibel WJ, Thompson RJ, Rowe GT, Pakulski JD (1991) Bacterial responses to temperature and substrate concentration during the Newfoundland spring bloom. Mar Ecol Prog Ser 75:143-159

Porter KG, Feig YS (1980) The use of DAPI for identifying and counting the aquatic microflora. Limnol Oceanogr 25:943-948

Putt M, Stoecker DK (1989) An experimentally determined carbon : volume ratio for marine 'oligotrichous' ciliates from estuarine and coastal waters. Limnol Oceanogr 34:1097-1103

Putt M, Stoecker D, Alstatt J (1991) Bacterivory in McMurdo Sound. 1. Grazing by heterotrophic nanoflagellates. Antarct J US 26:139-140

Riedel A, Michel C, Gosselin M (2007) Grazing of large-sized bacteria by sea-ice heterotrophic protists on the Mackenzie Shelf during the winter-spring transition. Aquat Microb Ecol 50:25-38

Russell NJ, Harrisson P, Johnston IA, Jaenicke R, Zuber M, Franks F, Wynn-Williams D (1990) Cold adaptation of microorganisms. Philos Trans R Soc Lond Biol Sci 326: 595-611

Editorial responsibility: Urania Christaki, Wimereux, France
Sala M, Arin L, Balagué V, Felipe J, Guadayol Ò, Vaqué D (2005) Functional diversity of bacterioplankton assemblages in western Antarctic seawaters during late spring. Mar Ecol Prog Ser 292:13-21

> Salat J, Marrasé C (1994) Exponential and linear estimations of grazing on bacteria: effects of changes in the proportion of marked cells. Mar Ecol Prog Ser 104:205-209

Sarmiento JL, Slater R, Barber R, Bopp L and others (2004) Response of ocean ecosystems to climate warming. Global Biogeochem Cycles 18:GB3003

> Sherr EB, Sherr BF (2002) Significance of predation by protists in aquatic microbial food webs. Antonie Leeuwenhoek 81:293-308

> Sherr EB, Sherr BF, Fessenden L (1997) Heterotrophic protists in the central Arctic Ocean. Deep-Sea Res II 44:1665-1682

Sieracki ME, Johnson PW, Sieburth JM (1985) Detection, enumeration, and sizing of planktonic bacteria by imageanalyzed epifluorescence microscopy. Appl Environ Microbiol 49:799-810

Simon M, Azam F (1989) Protein content and protein synthesis rates of planktonic marine bacteria. Mar Ecol Prog Ser 51:201-213

Smith DC, Azam F (1992) A simple economical method for measuring bacterial protein synthesis rates in seawater using ${ }^{3} \mathrm{H}$-leucine. Mar Microb Food Webs 6:107-114

Steward GF, Smith DC, Azam F (1996) Abundance and production of bacteria and viruses in the Bering and Chukchi Seas. Mar Ecol Prog Ser 131:287-300

> Vaqué D, Gasol JM, Marrasé C (1994) Grazing rates on bacteria: the significance of methodology and ecological factors. Mar Ecol Prog Ser 109:263-274

- Vaqué D, Calderón-Paz JI, Guixa-Boixereu N, Pedrós-Alió C (2002a) Spatial distribution of microbial biomass and activity (bacterivory and bacterial production) in the northern Weddell Sea during the austral summer (January 1994). Aquat Microb Ecol 29:107-121

- Vaqué D, Guixa-Boixereu N, Gasol JM, Pedrós-Alió C (2002b) Distribution of microbial biomass and importance of protists in regulating prokaryotic assemblages in three areas close to the Antarctic Peninsula in spring and summer 1995/96. Deep-Sea Res II 49:847-867

Vaqué D, Agusti S, Duarte CM (2004) Response of bacterial grazing rates to experimental manipulation of an Antarctic coastal nanoflagellate community. Aquat Microb Ecol 36:41-52

Vaqué D, Guadayol Ò, Peters F, Felipe J and others (2008) Seasonal changes in planktonic bacterivory rates under the ice-covered coastal Arctic Ocean. Limnol Oceanogr 53:2427-2438

> Vazquez-Dominguez E, Peters F, Gasol JM, Vaqué D (1999) Measuring the grazing losses of picoplankton: methodological improvements to the use of fluorescently labeled tracers combined with flow cytometry. Aquat Microb Ecol 20:119-128

> Verity PG, Langdon C (1984) Relationships between lorica volume, carbon, nitrogen, and ATP content of tintinnids in Narragansett Bay. J Plankton Res 6:859-868

Weinbauer MG (2004) Ecology of prokaryotic viruses. FEMS Microbiol Rev 28:127-181

Submitted: April 7, 2008; Accepted: October 10, 2008

Proofs received from author(s): January 16, 2009 